\title{
Preview-Review Bilingual Instructional Tools Development with Discovery Learning Model Setting to Enhancing Student's Conceptual Understanding and Speaking Ability
}

\author{
Luh Mitha Priyanka ${ }^{1 *}$, I Nyoman Selamat ${ }^{2}$ \\ 1,2 Universitas Pendidikan Ganesha, Singaraja, Indonesia \\ *e-mail: luh.mitha@undiksha.ac.id
}

\begin{abstract}
This study aimed to analyze the validity categories and the effectiveness of preview-review bilingual instructional tools with discovery learning model setting in enhancing conceptual understanding and speaking ability. This study was research and development ( $R$ \& $D)$ using ADDIE developmental model consisting of analyzing, design, develop, implementation, and evaluation. The data collection was done through non-test techniques using product validation sheets, learning observational sheet, and observational sheet for speaking ability and test techniques using an assessment sheet for measuring conceptual understanding. The validity of preview-review bilingual instructional tools with discovery learning model setting was analyzed qualitatively based on 5-point scale conversion table. The effectiveness of preview-review bilingual instructional tools with discovery learning model setting in the implementation stage was analyzed based on the average of the gain score. The result showed that the validity of preview-review bilingual instructional tools with discovery learning model setting was 3.60 for the content and 3.55 for the language which is in very good category and the developed of preview-review bilingual instructional tools with discovery learning model setting was effective in enhancing conceptual understanding and speaking ability based on average gain score.
\end{abstract}

Keywords: Instructional Tools, Preview-Review, Conceptual Understanding, Speaking Ability

\section{Introduction}

Bilingual learning is a method of learning by using two languages (English and Indonesia) in the entire of learning process until assessment implementation (Hidayati, 2020; Tirtayani et al., 2017). This method aims to improve English competence and also understanding science concept. Many studies show that bilingual environment can give students many benefits and advantages. Being bilingual has connected to a number of cognitive advantages. Cognitive function refers to the mechanism of brain acquiring information. Students who are raised in bilingual environment have been found to be better competence than their monolingual peers at focusing on a task while tuning out disruption (Hidayati, 2020; Pransiska, 2017). There are two important factors in bilingual learning. First, teacher and student are trained to be persistent in carrying out bilingual learning. Second, bilingual learning which implemented can help student to be more understand in English literature (Nuha, 2014; Pransiska, 2017). Bilingual learning within the pedagogic context of the school should also include bilingual classes in different subjects. The second language should be the language used in class. Bilingual teaching should involve an improvement in the language as well as competence and knowledge in the subject itself. This is what intercultural learning is about and it brings a lot of new perspectives and chances for teachers and learners as well as concerning the language and the specific subject knowledge (Kokturak et al., 2016).

Science Education Study Program has several courses which is deliver using bilingual. Basic Science is one of them. This course discusses the concepts of science that are essential for junior high school, covering problems and investigations that attract the attention of students from the surrounding environment. However the implementation of bilingual learning in this course isn't optimal. This is because the planning and

\footnotetext{
${ }^{*}$ Corresponding author.
}

Received February 10, 2021; Accepted April 10, 2021; Available online September 25, 2021

Copyright (C) 2021 by Author. Published by Universitas Pendidikan Ganesha. 
implementation of bilingual learning is still dominated by using Bahasa. Instructional tools which using in this course seventy five percent still using Bahasa. Syllabi, Semester Lesson Plan, Student Worksheet and handout still in Bahasa, meanwhile only assessment as instructional evaluation using English. Instructional tools which isn't suitable can be one of the factor which make bilingual learning not implemented optimally (Wiratini et al., 2013).

Instructional tools are all kinds of materials that are used to assist educators in implementing the teaching and learning activities in the classroom (Abadi \& Assaat., 2017; Amir et al., 2019). Instructional tools refer to the channels of communication which an instructor or teacher can use to concretize a concept during teaching and learning process. They can also be defined as any collection of materials including animate and inanimate objects and human and non-human resources that a teacher may use in teaching and learning process to ease, encourage, improve and promote teaching and learning activities (Anuvervely \& Fauziati, 2019). Instructional tools materials in teaching could be classified into: (1) visual material: such as textbooks, newspaper, picture, diagram, real object studies, etc.; (2) audio materials: appeal to the sense of hearing, such as cassette tape recording, teachers voice, language laboratories etc.; (3) audio-visual materials: appeal to both sense of hearing and sight, such as video recording, film trips etc.; (4) two-dimensional instructional materials: include graphs, chart, posters, comics, cartoons, etc (Utami et al., 2019). The effectiveness and suitable of instructional tools in promoting students" academic performance in teaching and learning is indisputable. It provides the much needed sensory experiences needed by the learners for an effective and meaningful behavioural change. Instructional tools are meant to improve the quality of education for effective academic performance of students in schools (Ajoke, 2017). Because of many benefit using instructional tools in learning process, teacher ability to create a suitable instructional tool for achieve learning outcome is very important.

Bilingual instructional tools which is accordance with the characteristics of students in Science Education is bilingual instructional tools with preview review model. This instructional tools combines Bahasa and English in every learning activity. In this model the introduction stage will carried out in one language for example Bahasa, and continue using English in the next stage of bilingual learning. For the third step will be carried out using combine two languages (Ovando \& Collier, 1985). Preview review model is an innovative model to increasing student's creativity and learning outcome. This model help student to be more understanding about material which is deliver in bilingual learning (Wondal, 2016).

Preview-review bilingual instructional tools also aligned with discovery model setting. Discovery model is a learning model that involves the active participation of students in exploring and discovering their own knowledge and use it in problem solving. Discovery learning is a kind of student centered learning method, it does not mean instructors are useless in the learning model (Sahara et al., 2017). This model will encourage students to ask questions and formulate their own tentative answers, and to deduce general principles from practical examples or experiences. This model requires that the student participates in making many of the decisions about what, how, and when something is to be learned and even plays a major role in making such decisions. Instead of being 'told' the content by the teacher, it is expected that the student will have to explore examples and from them 'discover' the principles or concepts, which are to be learned (Ananta, 2016). Based on many advantages using discovery learning, designing preview review instructional tools with discovery leaning model setting is expected to enhancing student's conceptual understanding and speaking ability that are valid, practical, and effective. This study aimed to analyze the validity categories and the effectiveness of preview-review bilingual instructional tools with discovery learning model setting in enhancing conceptual understanding and speaking ability.

\section{Method}

The developed of preview-review bilingual instructional tools with discovery learning model setting aimed for enhancing students' conceptual understanding and speaking ability. 
The developmental procedure was based on ADDIE which consisting of analyze need assessment, design product based on need assessment, develop product which test by expert's judgment, limiting product implementation in basic science course, and evaluation based on the implementation as seen in Figure 1.

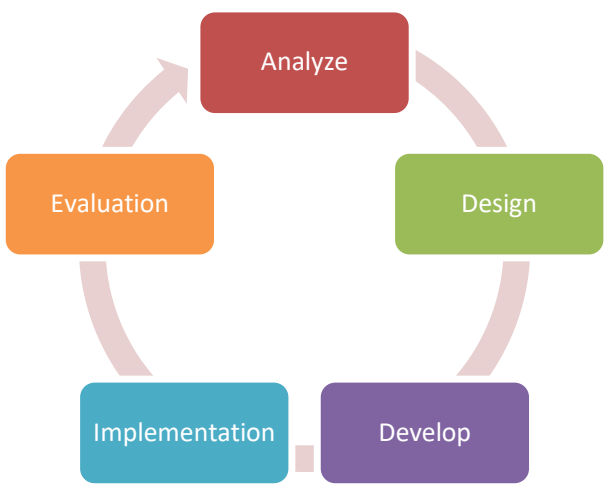

Figure 1. ADDIE Developmental Model

Analyze stage is the first stage of this developmental procedure. This stage is the most important one before creating the plan, developing, or even implementing the product. In this stage there are three main things to analyze such as literature analyzing, need assessment analyzing, and student's analyzing. Student's analyze is very important to determine suitable instructional tools which can be applied according the student's characteristics. We must pay attention to their needs, problems, academic abilities, activities, process skills, English language skills, attitude. In order to identify that, we do in by student and lectures' interview. Design stage is the next stage of ADDIE developmental procedure. In this stage we must think about how design instruction can really be effective in ways to solve the problems which has been defined in the analyze stage. Furthermore, in design phase we do several things such as (1) reviewing theories to improve the learning quality. Based on this review we select to use Discovery Learning Model as a model to apply preview review bilingual instructional tools in Basic Science 1 class, (2) designing preview review bilingual instructional tools which accordance with Discovery Learning model setting.

This third stage is a product realization stage. The solution which has been designed in the previous stage is produce as an initial prototype. This preview review bilingual instructional tools which accordance with Discovery Learning model setting needs to be tested for the validity. The validity test aimed to measure the feasibility of this product which carried out by two expert judges. Based on the validity result, the product must be revision to become prototype 2 which ready to implement. Implementation stage is about transforming our plan into action. At this stage, the implementation of instructional tools is carried out in the form of field trials to determine the effectiveness of this product. The final process in ADDIE model is Evaluation stage. In this stage we made the final revision of this product based on the field trials to make sure that the product can be used in larger scope. Based on need assessment which conduct by interview with lecture and students, the product which develop are syllabi and learning equipment (semester lesson plan, worksheet, handout, and assessment). Data collection techniques used in this study is in the form of product validation sheets for reveal the feasibility preview-review bilingual instructional tools and assessment for measuring student's conceptual understanding and speaking ability. Data analysis performed include feasibility preview-review bilingual instructional tools which scored by two expert lecturers. Validation sheets to measure the feasibility of this product will analyze using scale conversion 5 (Widoyoko, 2017). Meanwhile, assessment for measuring student's conceptual understanding and speaking ability will analyze using gain score in three categories as seen in Table 1 below. 
Table 1. Assessment Criteria

\begin{tabular}{cc}
\hline Interval & Criteria \\
\hline$g>0.7$ & High \\
$0.3 \leq \mathrm{g} \leq 0.7$ & Medium \\
$\mathrm{g}<0.3$ & Low \\
\hline
\end{tabular}

\section{Result and Discussion}

\section{Results}

Analyze Stage

The first stage carried out by analyzing several things such as literature analyzing, need assessment analyzing, and student's analyzing. The result of analyze stage can be seen in Table 2.

Table 2. Result of Analyze Stage

\begin{tabular}{ll}
\hline \multicolumn{1}{c}{ Analyze } & \multicolumn{1}{c}{ Result } \\
\hline \multirow{3}{*}{ Literature Analyzing } & $\begin{array}{l}\text { 1. The importance practicing English } 21^{\text {st }} \text { century skills } \\
\text { 2. Preview Review model in developing bilingual } \\
\text { learning environment }\end{array}$ \\
The implementation of bilingual learning in Basic \\
Student Analyzing & $\begin{array}{l}\text { Science course isn't optimal } \\
\text { Find out that Preview Review model is the best } \\
\text { instructional model in learning Basic Science based on } \\
\text { student's characteristic. }\end{array}$ \\
\hline
\end{tabular}

\section{Design Stage}

The second stage of this developmental model is design stage which involves using outputs from analyze stage to plan a strategy for developing preview-review bilingual instructional tools. The result of design stage can be seen in Table 3.

Table 3. Result of Design Stage

\begin{tabular}{|c|c|c|c|}
\hline \multicolumn{3}{|c|}{ Design } & Result \\
\hline Content in Bas & Scienc & Jourse & $\begin{array}{l}\text { Focusing on biodiversity and temperature content in } \\
\text { Basic Science course }\end{array}$ \\
\hline $\begin{array}{l}\text { Instructional } \\
\text { developed }\end{array}$ & Tools & which & $\begin{array}{l}\text { The instructional tools which developed are syllabi, } \\
\text { semester lesson plan, handout, student's worksheet, } \\
\text { and assessment evaluation }\end{array}$ \\
\hline The objective & & & Formulate instructional tools' objective \\
\hline
\end{tabular}

\section{Development Stage}

In this stage preview review bilingual instructional tools which accordance with Discovery Learning model setting needs to be tested for the validity. The validity will be tested by two lectures which expert in content and language. The validity test aimed to measure the feasibility of this product as seen in table 4 .

Table 4. Result of Product's Feasibility

\begin{tabular}{ccc}
\hline \multirow{2}{*}{ Assessment } & \multicolumn{2}{c}{ Average } \\
\cline { 2 - 3 } & Step 1 & Step 2 \\
\hline Content & 2.75 & 3.60 \\
Language & 2.60 & 3.55 \\
\hline
\end{tabular}


The feasibility of preview review bilingual instructional tools which developed through two stages. The average assessment in content and language of this product by expert lecturers for the first stage get 2.75 and 2.60 which in good criteria. This score is not enough to categorize that the product development is worth using (>2.8). This is why revision is needed to make it more perfect. The developed of this product can be re-assessed by the expert lecturer through a second stage assessment by revisions including several parts, such as 1) in learning outcome there are still verb which isn't operational to measure, 2) students learning activity which listed in handout must be explicitly poured in separate worksheet, 3) the reference which used must be more varied, 4) the questions for assessment must be presented with local context, 5) several operational verbs isn't suitable with the questions, 6) there is a question which not contain a homogenous option. The product which has been revised are given back to the expert lecture for the second step of validity. The second validation result obtained 3.60 for the content and 3.55 for the language which is in very good category. The results of product validation in this second stage shown that the preview review bilingual instructional tools which developed is suitable for use in bilingual learning.

\section{Implementation Stage}

In this stage instructional tools which has been revision and become prototype 2 will be implemented in the form of field trials to determine the effectiveness of this product. Preview review bilingual instructional tools with discovery learning model setting will implemented in Basic Science course to measure understanding concept and student 'speaking ability. The result of implementation stage present in Figure 2.

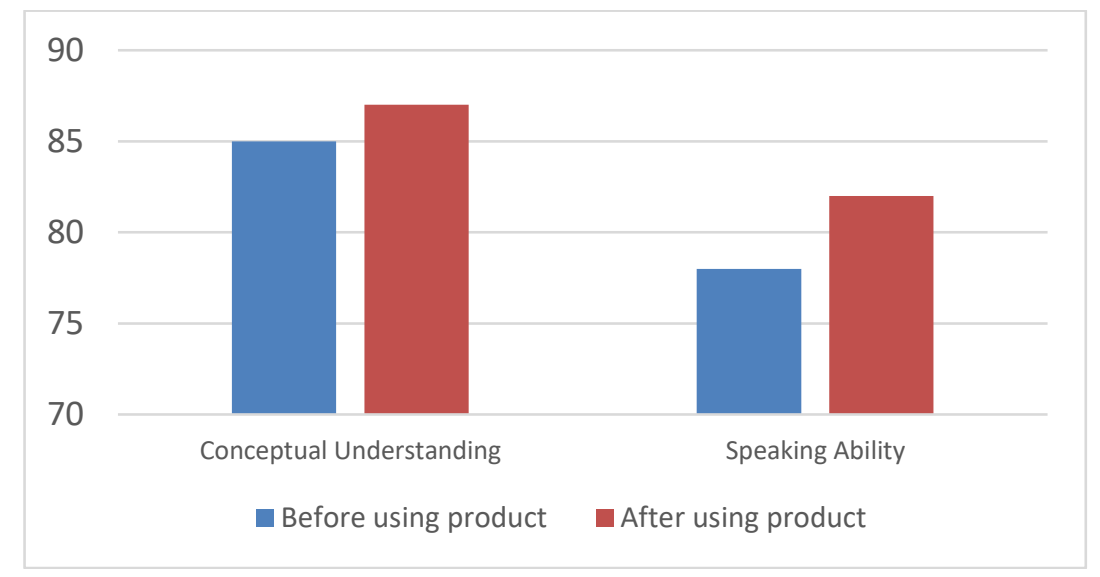

Figure 2. Result of Implementation Stage

The last stage of ADDIE development model is the evaluation of instructional tools based on the implementation in class. At this stage, the researcher made the final revision of preview review bilingual instructional tools based on observation sheets while implementing this product in previous stage. The final revision aimed to verify that this product is appropriate and can be used in wider scope for enhancing conceptual understanding and speaking ability.

\section{Discussion}

Designing preview review instructional tools with discovery model setting aimed to enhance student's conceptual understanding and speaking ability in Basic Science course. The instructional tools designing using ADDIE model with the first step of this developmental model is analyze. The first stage carried out by analyzing several things such as literature analyzing, need assessment analyzing, and student's analyzing. The result of literature analyzing is basic theory of the importance practicing English in $21^{\text {st }}$ century skills. English plays an important role for communication, media and entertainment, seeking information, getting job, international relation, and so on (Pardede, 2020; Reddy, 2016). Undoubtedly, English plays a much greater role in the world that it is inevitable for people to ignore it fully. 
It has a bright future, it helps connect in a global world, and it can also help in personal and professional life (Nishanti, 2018).

Need assessment analyzing is carried out by observations and interviews with lecturer. The purpose of this analysis is to find out the real problems that occur in Basic Science learning. The observation, the problems which occurs in the learning process is the implementation of bilingual learning in Basic Science course isn't implemented optimally. This is because the planning and implementation of bilingual learning is still dominated by using Bahasa. There aren't any instructional tools which support bilingual learning in this course. Even though Basic Science is a course which must carried out in Bilingual learning, but the fact there isn't enough preparations for implementing it. This is become one big problem which must be faced and solved by lectures.

Student's analyzing aimed to determine the suitable method for learning science based on their characteristics. Bilingual instructional tools which is accordance with the characteristics of students in Science Education is bilingual instructional tools with preview review model. This instructional tool combines Bahasa and English in every learning activity. In this model the introduction stage will carried out in one language for example Bahasa, and continue using English in the next stage of bilingual learning. For the third step will be carried out using combine two languages (Ovando \& Collier, 1985). The implementation of bilingual learning in Basic Science 1 are expected to be more effective using preview review bilingual instructional tools. Furthermore, the learning model which support this instructional tool is discovery learning model. Discovery learning model can encourage motivation, active involvement, and creativity. Hence, preview-review bilingual instructional tools with discovery learning model setting are expected to enhancing student's conceptual understanding and speaking ability.

The result from analyze stage use to the next stage for making practical decisions. This include designing instructional tools with preview review model such as focusing the content in Basic Science for this instructional tool, and decide what are instructional tools which will develop using preview review model. After decide what are the instructional tools which will develop, the objective of each instructional tools must be formulate. The content material in Basic Science which use in instructional tools based on curriculum are biodiversity and temperature. Meanwhile the instructional tools which develop are syllabi, lesson plan, worksheet, handout, and assessment. Based on the technology which is used, instructional tools can be classified as written material or unwritten material, including handouts, books, modules, posters, brochures, student worksheets, wallcharts, photos, or drawings, and leaflets (Aidil \& Razak, 2019).

Before implemented in class, this instructional tool should be tested by expert judges regarding its validity in development stage. The results of validation process shown that the preview review bilingual instructional tools which developed is suitable for use in bilingual learning. All of components of instructional tools including syllabi and learning equipment (semester lesson plan, worksheet, handout, and assessment) get more than 3.50 with very valid criteria. The principle of syllabi development includes scientific, relevant, systematic, consistent, adequate, actual and contextual, flexible, and comprehensive. While developing syllabi, there are several steps which should follow including the study of core competence and basic competence, identify the topic subject, develop the learning activities, formulate the indicators of achievement of competence, determine the type of assessment, determine the allocation of time, and determine the source of learning (Hariapsari et al., 2018). Lesson plan is also one of instructional tools which develop to enhance conceptual understanding and speaking ability. Lesson plan is a grip for teachers in implementing learning to achieve one or more basic competencies set out in the standard competencies. There are several principles that must be considered by a teacher in the development of lesson plan (Ratnawati, 2017). First, it consists of goals, activities, sequencing (the order in which activities will be used, including opening and closing activities, timing (how much time will spend on different activities), grouping (when the class will be taught as a whole and when the students will work in pairs or groups, and resources. 
Next, effective instructional plans are necessary for teaching that leads to improved student learning. Those plans also provide teachers with clear documentation of what has been taught. Instructional tools which develop in preview review model aligned with discovery learning setting are valid to implement in Basic Science course. The aspects that were validated by expert judges were the feasibility of the content (material and speaking ability questionnaire and cognitive learning outcomes) and the feasibility of language. Some comments from validator which should revise before using this product in the next stage are some typing errors, learning objectives should be more operationalized, some question indicators in assessment are not appropriate, and the images used in the questions should more clarified and accompanied by sources.

The next stage in ADDIE model is implementation. In this stage, instructional tools which has been revise will be implemented in the form of field trials to determine the effectiveness of this product. Preview review bilingual instructional tools with discovery learning model setting proved effective for enhancing conceptual understanding and speaking ability based on the assessment result after using this product. The result in implementation stage showed that after using preview review bilingual instructional tools, both of this skills improving from 85 to 87 for conceptual understanding and 78 to 82 for speaking ability. Not only speaking ability but also science conceptual understanding is improving after students using this bilingual instructional tools. Before using this instructional tools, student difficult to understand some english terms which suitable in science context. English for science context are different with english in general. Some term can make student's confuse. However, after using bilingual preview review instructional tools, they more understand about english term specific for science such as forcé not style, properties of matter not characteristic of matter, and so on.

This findings supported the research who said that the teachers noticed that the bilingual learning programmed may foster more direct attention not only language but also the content that use (Suwaranak, 2015). As one of the teachers stated, student's ability will improve when they are more aware of their different languages as they are encouraged to use both regularly. Other previous study also said that bilingualism in education automatically perceived in two languages as the bilingual has one consciousness (Veliyeva, 2015). It means that knowledge perceived in one language can be easily applied in the other language community when communicating in Language 2. This advantage enriches the bilingual individual's life experience and increases his or her competency. The instructional tools which develop should be implemented in class regularly to foster student understanding and also speaking ability. Preview review model conducted by team teaching with three stages of language which use in learning process (Suma, 2011). The introduction will be conduct with one teacher with one language, the next step will continue in English, and the last step will end by the other teacher with both of the language. Using language systemically in every learning step makes students not confused and more understand. Preview review model consider to be an alternative bilingual learning in Indonesia.

Designing preview review instructional tools aligned with discovery learning setting also proved effective to enhancing science concept and speaking ability. Discovery learning is effective and has positive impact on a student's conceptual understanding and critical thinking (Ramadhan et al., 2020). This model is a learning model that helps students to find a new concept and discover a new knowledge from activities such as creating hypothesis, estimating, and trying beneath the teacher's help. Discovery learning method is a learning situation in which the principal content of what is to be learned is not given but must be independently discovery by the students. By using discovery learning, students can also think, analyze and try to solve their problem by themselves. In additionally the method that has a purpose to make independent and creative growth in studying, the students can make innovation in the teaching-learning process (Musdizal \& Hartono, 2020).

From the result obtained before using bilingual preview review instructional tools model, the student' speaking ability never been measured in learning process because there isn't instructional assessment which suitable for measuring that. The bilingual learning also not implemented well because the process only uses 25\% English, while still dominated by 
using Bahasa. Suitable instructional tool is the key in every learning process. These results were also obtained from research who stated that instructional tools play a very important role in the teaching-learning process (Bukoye., 2019). They allow students to interact with words, symbols and ideas in ways that develop their abilities in reading, listening, solving, viewing, thinking, speaking, writing, using media and technology. Using a suitable instructional tool will make enhancement of student's memory level and improving their ability.

The last stage of developmental model ADDIE is evaluation. After implementing this product in class, teacher and student must assess while this product effective or not. Based on observation sheets while implementing this product in previous stage, the researcher made the final revision of preview review bilingual instructional tools. The final revision aimed to verify that this product is appropriate and can be used in wider scope for enhancing conceptual understanding and speaking ability. Evaluation is a systematic process that determines the quality and effectiveness of the teaching design in the final product (Alwi \& Kamis, 2019). This is a crucial phase while the researcher needs to constantly evaluate the advantages and disadvantages of each previous phase which are analysis, design, development and implementation.

The result of the developing preview review bilingual instructional tools which valid and effective based on empirical result is recommended for implementing in Basic Science course. This instructional tool will help students in bilingual learning to improve their conceptual understanding and speaking ability. Furthermore, this instructional tool will help to make Basic Science course implemented optimally as a selected course which should implement in bilingual learning. Discovery learning, it is similar to Yuliani's statement [8], which states that discovery learning is effective and has a positive impact on a student's conceptual understanding and critical thinking. The discovery learning model is a learning model that is served to students to guide them to find a new concept. Students are expected to be able to actively discover new knowledge like creating a hypothesis, estimating, and trying beneath the teacher's While the Student Worksheet using discovery learning models is structured, and indicators are used in accordance with the curriculum in the school. It is expected that student worksheets using discovery learning models can stimulate students to be more active in learning and also can improve students' mathematical reasoning and make it easier for teachers to provide assignments in mathematics learning. While the Student Worksheet using discovery learning models is structured, and indicators are used in accordance with the curriculum in the school. It is expected that student worksheets using discovery learning models can stimulate students to be more active in learning and also can improve students' mathematical reasoning and make it easier for teachers to provide assignments in mathematics learning.

\section{Conclusions and Suggestions}

The preview-review bilingual instructional tools with discovery learning model setting based on research results was very valid and effective. The validity of preview-review bilingual instructional tools with discovery learning model setting was 3.60 for the content and 3.55 for the language which is in very good category. This instructional tool was also effective in enhancing conceptual understanding and speaking ability based on average gain score. Based on the discussion, it is suggested to the lecturer in Basic Science 1 to use the preview-review bilingual instructional tools during her lecture, for enhancing student's conceptual understanding and speaking ability.

\section{Acknowledgements}

My deep thanks and appreciation to LP2M Universitas Pendidikan Ganesha that has been funding this research and we highly appreciate related parties who assisted us to finish this research. 


\section{References}

Abadi, K., \& Assaat. (2017). Development of Teaching Materials Based Interactive Scientific Approach towards the Concept of Social Arithmetic for Junior High School Student. Journal of Physics: Conference Series. https://doi.org/10.1088/1742-6596.

Aidil, A., \& Razak, A. (2019). Module Development Based on PBL (Problem Based Learning) on Environmental and Ecosystem Change Materials for Student of Class X SMAN 1 Singkarak. International Journal of Progressive Sciences and Technologies, 15(2), 46-52. https://ijpsat.ijsht-journals.org/index.php/ijpsat/article/view/1053/540.

Ajoke, A. . (2017). The Importance of Instructional Materials in Teaching English as a Second Language. International Journal of Humanities and Social Science Invention, 6(9), 36-44. http://www.ijhssi.org/papers/v6(9)/Version-3/F0609033644.pdf.

Alwi, A., \& Kamis, A. (2019). Using the ADDIE Model to Develop Green Skills Teaching Module. International Journal of Engineering Research and Application, 9(1), 53-57. http://www.ijera.com/papers/vol9no1/S2/I0901025357.pdf.

Amir, M., Muris, \& Arsyad, M. (2019). Pengembangan Perangkat Pembelajaran berbasis Pengalaman pada Peserta Didik Kelas XI IPA SMA Negeri 9 Pinrang. International Journal of Engineering Research and Application, 9(1), 53-57. https://ojs.unm.ac.id/JSdPF/article/view/1756/769.

Ananta, H. (2016). The Effect of Discovery Learning Method Application on Increasing Students' Listening Outcome and Social Attitude. Jurnal Dinamika IImu, 16(2), 291306.

https://journal.iainsamarinda.ac.id/index.php/dinamika_ilmu/article/view/552/pdf_41.

Anuvervely, G., \& Fauziati, E. (2019). Designing English Instructional Materials for Vocational High School: A Narrative Inquiry at SMK At-Thoat Toroh Purwodadi. International Proceeding The 2nd International Conference on Language, Literature and Teaching, 198-207. https://publikasiilmiah.ums.ac.id/handle/11617/11157.

Bukoye., R. (2019). Utilization of Instruction Materials as Tools for Effective Academic Performance of Students: Implications for Counselling. 2nd Innovative and Creative Education and Teaching International Conference.

Hariapsari, K., Tukiran, \& Sudibyo. (2018). Validity of Teaching Materials Based on SocioScientific Issues Approach on The Topic of Vibration, Waves, and Sound. IOP Journal of Physics. https://iopscience.iop.org/article/10.1088/17426596/1108/1/012034/pdf.

Hidayati, N. N. (2020). Rethinking the quality of children's bilingual story books. Al-Asasiyya: Journal Of Basic Education, 4(1), 46. https://doi.org/10.24269/ajbe.v4i1.2226.

Kokturak, S., Odeciaglu, M., \& Uysal, N. (2016). Bilingualism and Bilingual Education, Bilingualism and Translational Action. International Journal of Linguistics, 8(3). http://www.macrothink.org/journal/index.php/ijl/article/view/9601.

Musdizal, \& Hartono, R. (2020). The Influence of Discovery Learning Method and Video on Students' Writing Skill. International Journal of Scientific \& Technology Research, 9(1), 1152-1155. http://www.ijstr.org/final-print/jan2020/-The-Influence-Of-DiscoveryLearning-Method-And-Video-On-Students-Writing-Skill.pdf.

Nishanti, R. (2018). The Importance of Learning English in Today World. International Journal of Trend in Scientific Research and Development, 3(1). https://www.ijtsrd.com/humanities-and-the-arts/sociology/19061/the-importance-oflearning-english-in-today-world/rajathurai-nishanthi.

Nuha, U. (2014). Meningkatkan Kualitas Pelayanan Perpustakaan dengan Pendekatan $\begin{array}{llll}\text { Bilingual. Jurnal } & \text { Perpustakaan }\end{array}$ https://journal.iainkudus.ac.id/index.php/Libraria/article/view/1190.

Ovando, C. J., \& Collier, V. P. (1985). Bilingual and ESL Classrooms. McGraw-Hill Book Company.

Pardede, P. (2020). Integrating the 4Cs into EFL Integrated Skills Learning. Journal of English Teaching, 6(March), 71-85. https://doi.org/10.33541/jet.v6i1.190.

Pransiska, P. (2017). Benefits of Bilingualism in Early Childhood: A Booster of Teaching 
English to Young Learners. Advances in Social Science, Education and Humanities Research, 58, 390-393. https://www.atlantis-press.com/proceedings/icece$16 / 25869360$.

Ramadhan, K., Suparman, Hairun, Y., \& Bani, A. (2020). The Development of Hots-based Student Worksheets with Discovery Learning Model. Journal of Education Research, 8(3), 888-894. https://www.hrpub.org/download/20200229/UJER20-19514695.pdf.

Ratnawati. (2017). Developing a Lesson Plan for Teaching English for Specific Purposes to Adult Learners at a Private University. Journal of Applied Linguistic and Literacy, 1(2), 33-42. https://jurnal.unigal.ac.id/index.php/jall/article/view/1729/2423\#.

Reddy, M. (2016). Importance of English Language in Today's World. International Journal of Academic Research, 3(4), 179-184. http://ijar.org.in/stuff/issues/v3-i4(2)/v3-i4(2)a021.pdf.

Sahara, R., Mardiyana, \& Sari, R. (2017). Literatur Study: Discovery Learning Teaching Model trough Somatic Auditory Visual Intelectual Approach in Mathematic Teaching. 4 Th ICRIEMS Proceedings, 135-140. http://seminar.uny.ac.id/icriems/sites/seminar.uny.ac.id.icriems/files/prosiding2017/M E20 Rifki Sahara.pdf.

Suma, K. (2011). Pengembangan Model Pembelajaran Bilingual Preview-Review Berbasis Inkuiri. Jurnal Pendidikan Dan Pengajaran, 44(1), 1-9. https://ejournal.undiksha.ac.id/index.php/JPP/article/view/132/126.

Suwaranak, K. (2015). Learning English as Thai Adult Learners: An Insight into Experience in Using Learning Strategies. English Language Teaching, 8(12), 144-157. http://www.ccsenet.org/journal/index.php/elt/article/view/55085.

Tirtayani, L. A., Magta, M., \& Lestari, N. G. A. M. Y. L. (2017). Teacher Friendly e-Flashcard: a development of bilingual learning media for young learners. Journal of Education Technology., 1(1), 18-29. https://doi.org/http://dx.doi.org/10.23887/jet.v1i1.10080.

Utami, M. S., Fauziati, E., \& Rochsantiningsih, D. (2019). English Instructional Materials for the Integrated Islamic Elementary School (SDIT). Journal of Teaching \& Learning English in Multicultural Contexts (TLEMC), 3(2), 74-80. https://core.ac.uk/download/pdf/276633698.pdf.

Veliyeva, M. (2015). Bilingualism in Education. Theory and Practice in Language Studies, $5(12)$

https://www.academypublication.com/ojs/index.php/tpls/article/view/tpls05122448245 2/501.

Widoyoko, E. (2017). Evaluasi Program Pelatihan. Pustaka Pelajar.

Wiratini, A., Suparta, N., \& Sadra, W. (2013). Pengembangan Perangkat Pembelajaran Billingual Tipe Partial Immersion dengan Setting Pembelajaran Kooperatif Tipe STAD. E-Journal Program Pascasarjana Universitas Pendidikan Ganesha, 2(2). https://oldpasca.undiksha.ac.id/e-journal/index.php/JPM/article/view/761.

Wondal, R. (2016). Penggunaan Model Pembelajaran Preview, Questions, Read, Reflect, Recite, Review (Pq4r) untuk Meningkatkan Aktivitas dan Hasil Belajar Biologi. Jurnal Pendidikan Dasar, http://journal.unj.ac.id/unj/index.php/jpd/article/view/613.

128-139. 